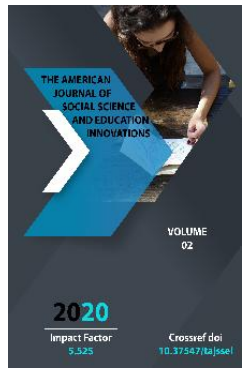

Journal Website: http://usajournalshub.c om/index,php/tajssei

Copyright: Original content from this work may be used under the terms of the creative commons attributes 4.0 licence.

\section{What Model Of Anti-Corruption Body Is Needed For Uzbekistan?}

Qunduz Rozimova

Tashkent State University Of Law Criminal Law And Criminology Senior Teacher Of The Department, Uzbekistan.

Ulugbek Aloev

Prosecutor General's Office Of The Republic Of Uzbekistan Independent Researcher Of The Academy, Uzbekistan.

\title{
ABSTRACT
}

This article examined the multifunctional, preventive and law enforcement models of state bodies of foreign countries to combat corruption and the author analyzes their positive and negative features. Based on the experience of foreign countries, proposals and a recommendation have been developed to organize the activities of the anti-corruption body in Uzbekistan, proposed in the Message of the President of the Republic of Uzbekistan Shavkat Mirziyoyev to the Chambers of the Oliy Majlis on January 24 of this year.

\section{KEYWORDS}

Corruption, corruption crimes, models of anti-corruption bodies, civil servants, government anticorruption policies, causes and conditions conducive to corruption etc.

\section{INTRODUCTION}

From the first years of independence, Uzbekistan paid serious attention to the fight against corruption. At the initial stage, the Constitution was adopted and the cornerstone of an anti-corruption legal policy was laid, then the anti-corruption criminal legislation was improved and the powers of law enforcement bodies in this area were clearly defined.
In recent years, special attention has been paid to the fight against corruption, which has reached a qualitatively new level. In particular, the strategy actions in five priority areas of the development of the Republic of Uzbekistan for 2017-2021 determines the improvement of organizational and legal mechanisms to combat corruption and 
increase the effectiveness of anti-corruption measures [1].

Although the fight against corruption is a complex set of measures, there are differing views among scholars as to whether the task of their development, implementation and coordination should be carried out by a separate state body, but they can be conditionally divided into two groups.

Proponents of the first group argue that the creation of a separate anti-corruption body will lead to a reduction in the overall level of corruption, faster achievement of goals and improvement of their position in the rankings of international organizations [2]. Representatives of the second group note that a separate state body to combat corruption will be established mainly in developing countries [3].

United Nations Convention against Corruption (New York, 2003, October 31) Article 5 provides that Member States must ensure the existence of an independent body or bodies responsible for the prevention of corruption. (Uzbekistan joined on July 7, 2008) [4].

The Republic of Uzbekistan is gradually fulfilling the requirements of this Convention. In this regard, anti-corruption measures include, first of all, strict adherence to the principle of separation of powers formed over several years, ensuring restraint and balance of interests, taking measures to increase legal awareness and legal consciousness of the population, creating decent conditions and social protection for civil servants and strengthening them gradually, taking into account the national mentality and specific customs of the people.

According to the above factors, the Law of the Republic of Uzbekistan "On Combating Corruption", adopted in 2017, directly delegates the fight against corruption to the following 6 entities:
- Republican interdepartmental commission on combating corruption and territorial interdepartmental commissions;

- Prosecutor General's Office;

- State Security Service;

- Ministry of Internal Affairs;

- Ministry of Justice;

- Department for Combating Economic Crimes under the Prosecutor General's Office [5].

In the recent years, these entities have taken significant measures to combat corruption. In particular, the mentioned law enforcement agencies revealed that in 2019, 455 heads of non-state-owned enterprises (380 in 2018) committed corruption-related crimes.

At the same time, further improving the effectiveness of measures taken by anticorruption agencies has begun to play an important role in creating a new image of Uzbekistan in the eyes of the international community.

Indeed, in the 2019 Transparency International Corruption Perceptions Index, Uzbekistan ranked 153 rd out of 180 [6], along with Cameroon, the Central African Republic and the Comoros. This necessitated a review of the system of combating corruption and, first of all, to pay special attention not to the fight against crime in this area, but to the elimination of the factors and causes that create the conditions for it.

In this context, in the Address of the President of the Republic of Uzbekistan Shavkat Mirziyoyev to the Oliy Majlis on January 24 in this year [7] and at the anti-corruption meeting on February 11 [8], proposing to establish a special responsible body with all the forces and means to combat corruption has played an important role in the country's history.

Then paragraph 53 of the State Program, approved by Decree of the President of the 
Republic of Uzbekistan dated 02.03.2020 No. 5953, instructed the Prosecutor General to develop a draft Decree of the President on the creation of a separate state body to combat corruption [9].

\section{MODELS OF ANTI-CORRUPTION BODIES}

The establishment of a separate state body to combat corruption directly requires the identification and analysis of the specifics of the existing models in foreign countries, their bitter experience and positive achievements, mistakes and shortcomings.

It should be noted that the adoption of one or another model of the state body for combating corruption depends on the political will and desire of the Head of State.

It should be noted that the exact copying of a model that has justified itself in a particular state may not only produce the expected positive result, but may have the opposite effect or lead to conflicts between public authorities.

Models of anti-corruption institutions are classified differently by scholars. For example, MM Polyakov considers it expedient to divide the separate anti-corruption structures of foreign countries into the following 2 groups:

1. Special anti-corruption bodies (Korea, Singapore, India);

2. Anti-corruption authorities (for example, the Justitie-Ombudsman in Finland) [10].

Today, the following three models of anticorruption institutions are widely used in foreign countries:

- multifunctional model;

- law enforcement model;

- preventive bodies [11].

\section{MULTIFUNCTIONAL MODEL}

The peculiarity of this model is that anticorruption bodies or institutions simultaneously have both preventive and law enforcement powers. A prime example of this model is the Hong Kong Independent AntiCorruption Commission [12].

The commission, which has 1,200 employees and works independently of all government agencies, organizes its anti-corruption activities in the following three main areas:

a) effective detection and investigation of corruption crimes;

b) the elimination of the causes and factors of corruption;

(c) Organizing public awareness campaigns to clarify the causes of corruption.

In turn, a number of positive aspects of the multifunctional model with such a wide range of capacities can be noted:

- The right to disclose a corruption crime against any public servant should encourage them to refrain from committing such crimes, and the inevitability of punishment must be ensured for any official who committed a crime;

- Provides a comprehensive analysis of identified crimes and their causal relationships to ensure the prevention of such crimes in the future;

- The correct choice of methods and directions of anti-corruption education of the population, taking into account the current situation, will ensure its effectiveness.

- In our opinion, the structure of a separate body, which is a multifunctional model of the fight against corruption and has unlimited powers:

- The main focus of their activities is on the detection of crimes and insufficient attention is paid to the prevention of offenses;

- To focus mainly on the detection of crimes related to domestic corruption 
and insufficient attention to crimes committed by high-ranking officials

- Involvement of employees of the organization in corruption crimes, abuse of power by exerting pressure on other state bodies and organizations using their powers;

- Can lead to strong conflicts and other negative consequences among other, state bodies especially law enforcement agencies.

\section{LAW ENFORCEMENT MODEL}

The distinguishing feature of this model from other models is that the main focus is on combating corruption crimes. In foreign countries, such a model usually manifests itself in two different forms. In the first case, the task of exposing and investigating corruption crimes is assigned to a separate state body (for example, the National AntiCorruption Bureau of Ukraine [13]), and in the second form, the task is assigned to the relevant state body or its structure (for example, the US Federal Bureau of Investigation [14]).

An important aspect of this model is that existing special organization in the anticorruption law enforcement model does not mean anti-corruption measures may always be successful in that country. For example, despite the fact that the Bureau is working hard to combat corruption [15], in 2019 in the Corruption Perceptions Index, Ukraine fell 6 places from 120th place in 2018 to 126 th place [16].

In addition, several attempts by the Prosecutor General's Office to initiate criminal proceedings against its director since the establishment of the National Anti-Corruption Bureau of Ukraine in 2015 are certainly evidence of disagreements between the two law enforcement agencies [17].
We can see a similar situation in other foreign countries.

Of course, such a model has its own positive and negative aspects, and in our opinion, the positive aspects are reflected in the following:

- Uncompromising fight against corruption-related crimes;

- Effective methods of combating corruption will be introduced in the system of state bodies;

- Effective cooperation will be established with civil society institutions and citizens in the fight against corruption.

- As the disadvantages of the law enforcement model, we can conditionally point to the following:

- The specific status of the body does not provide effective control over the staff of this body;

- The emergence of a specific "competitive environment" for the determination and detection of crimes with other government agencies tasked with combating corruption;

- Focusing on corruption crimes of highranking officials can lead to a decrease in the effectiveness of the fight against domestic corruption.

\section{PREVENTIVE ORGANS}

Typically, such bodies are established directly to carry out anti-corruption activities and the activities of such bodies will focus on anticorruption strategies, coordination of research in this area, methodological guidance to government agencies on corruption risk assessment and prevention, assessment of corruption risks in laws and their drafts, and others [18].

A vivid example of such a model is the AntiCorruption Service, which worked in France until 2016. This body, which reports to the Prime Minister and Minister of Justice of 
France, is responsible for collecting and analyzing information on cases of corruption, advising administrative and judicial authorities on this category of cases and implementing international cooperation [19].

It should be noted that this body, which was not sufficiently effective in the fight against corruption only because of its preventive function, was abolished in 2016 and transformed into an anti-corruption agency authorized to detect and investigate crimes related to corruption [20].

Another example of such a model is the AntiCorruption Council under the President of Russia, created by the Decree of the President of Russia in 2008.

The Council, consisting mainly of heads of governmental and non-governmental organizations, is tasked with preparing proposals for the development and implementation of anti-corruption policy, coordinating the activities of government agencies in the fight against corruption, monitoring the implementation of measures provided for in the National Anti-Corruption Program [21].

At the same time, for several years, Russian lawyers have been proposing the establishment of a special anti-corruption service [22].

Based on the above, it is expedient to list the following positive aspects of anti-corruption bodies:

- In the activities of preventive authorities, the main focus is on crime prevention;

- Allows for the implementation of important reforms in the fight against corruption through the analysis and improvement of existing legislation;

- Through the correct and effective organization of advocacy, it will be possible to provide civil servants with a "vaccine of honesty" and the formation of immunity against corruption.
- In turn, the following can be listed as the negative aspects of the body, which is assigned one preventive function

- Does not have the authority to make an independent decision on the legal assessment of the fact of the fight against corruption and take appropriate actions;

- Proposals for the implementation of state policy in the field of anti-corruption may not be relevant to the current situation and may not allow to achieve the expected results in this area in the future;

- Failure to take appropriate measures against other government bodies or officials may lead to non-compliance with the instructions of such a body.

As we have seen, each of the above models of foreign countries in the fight against corruption has its own advantages and disadvantages, which should be taken into account when creating an anti-corruption body in Uzbekistan.

At the same time, a number of serious questions related to the establishment of a state body and its legal status, the definition of its main functions, which did not exist before in the history of the country, need to be clarified:

- What is the status of the new body?

- How is the relationship with other government agencies?

- Will the new body be the only state body implementing anti-corruption policy, or will other government agencies continue to work in this direction?

- What are the main tasks of this body in its main activities?

Below we will try to answer each question in detail, based on the experience of foreign countries.

I. The status of the newly established body.

The anti-corruption bodies of most foreign countries, which rank high in the Corruption 
Perceptions Index, belong to a multifunctional and law enforcement model, which has the status of a law enforcement agency.

In particular, in Singapore (the Corruption Perceptions Index - 4[23]) the Law on Prevention of Corruption [24] gives the Bureau of Corruption Investigation all the powers inherent in law enforcement, while in Hong Kong (16th place [25]) the Law on the Independent Anti-Corruption Commission also gives the commission the powers of law enforcement agencies [26].

The Lithuanian Special Investigation Service (35th place [27]) and the Latvian AntiCorruption Bureau (44th place [28]) also have law enforcement status.

In turn, while we have a firm goal to fight corruption, we should also create a law enforcement agency, and give its employees career ranks.

This raises the legitimate question of whether it is appropriate for an anti-corruption body to be in the presence of a state body (e.g., parliament, government) or an official (e.g., prime minister or president) or to be established as an independent body.

In our opinion, the establishment of an anticorruption body under the supreme body of state power in order to increase its prestige will allow this body to put pressure on a particular body or official in the future, which may limit its quality of work or complete independence.

Therefore, it is advisable to establish a new body as an independent body, such as other law enforcement agencies (e.g., the Ministry of Internal Affairs, the Prosecutor's Office, the National Guard, etc.).

II. Organization of interaction with other public authorities.

Its accountability plays an important role in the new anti-corruption body's relations with other bodies. After all, the work performed by this body is evaluated by the body or officials to which it reports.

In countries with a republican form of government, such as Singapore and Lithuania, the anti-corruption body is directly accountable to the President or parliament and regularly reports on its activities.

In this regard, it is expedient to establish the body directly accountable to the President of the Republic of Uzbekistan and the chambers of the Oliy Majlis.

III. Establishment of a new body as the sole state body to implement anti-corruption policy.

Today, all state and economic bodies make a worthy contribution to the fight against corruption in our country. In our opinion, it is impossible to fight corruption in a society, no matter how strong it is, by the power of a single state body.

The goals can only be achieved if the whole society sincerely wants and strives for the complete elimination of corruption.

In addition, the removal of such authority from the law enforcement agencies involved in the fight against corruption in our country, and the transfer of this task to a single body can lead to it becoming a powerful punitive body that can take action against any official in the country.

Therefore, it is advisable to instruct the new body to coordinate the activities of other state bodies that conduct anti-corruption policies, and not a single state body that implements anti-corruption policies.

At the same time, in order not to duplicate the powers and responsibilities of anti-corruption bodies, it is necessary to clearly define which officials or civil servants will be involved in the fight against corruption.

In this way, other law enforcement agencies will continue to work to combat corruption in society. 
In this case, the entire system of law enforcement agencies will fight corruption uncompromisingly and the goal will be achieved faster.

\section{THE MAIN ACTIVITIES OF THE BODY}

As noted above, in the current context, the creation of a multifunctional model, that is, a body that is empowered with both preventive and anti-crime powers, is, in our view, the most appropriate approach.

At the same time, it is important to set specific tasks for the new body to combat corruption. Analyzing the United Nations Convention against Corruption and the experience of foreign countries, it is expedient to assign the following tasks to the new body:

formulation and implementation of state policy in the field of prevention and combating corruption;

conducting a comprehensive analysis of the state and trends of corruption in the country; timely prevention, detection, elimination, detection and investigation of corruption offenses, their consequences, causes and conditions;

elimination, as well as ensuring the inevitability of liability;

on the prevention and fight against corruption state bodies carrying out and participating in the activity and coordinating the work of organizations and ensuring their effective cooperation;

anti-corruption examination of adopted and current regulations;

development of international cooperation on the search and return of property acquired through corruption and placed abroad; implementation of systematic measures to strengthen the country's positive image in the international arena and increase its position in international rankings; ensuring the effective implementation and operation of a system for declaring and authenticating declarations of civil servants; public procurement and spending of the State budget

implementation of anti-corruption control in the field;

implementation of systemic measures aimed at raising the legal awareness and legal consciousness of the population in the field of prevention and combating corruption, the formation of an intolerant attitude to any form of corruption in society, as well as coordination of activities in this area, etc.

Conclusion. It should be noted that the structure of an independent multi-functional anti-corruption body in Uzbekistan:

creates unprecedented opportunities for the complete eradication of corruption through a separate body responsible for combating corruption;

Accelerates the involvement of all segments of the population, the best specialists in the fight against corruption, vaccination of all members of society with the "honesty vaccine",

mobilizes the main forces and means to prevent the early consequences of corruption; serves to eliminate various artificial barriers to the path of reform at a new stage of our development;

It will be an additional factor in further strengthening the positive image of our country in the world, ultimately attracting more foreign direct investment, strengthening the trust of partners;

allows for the introduction of effective mechanisms to combat the "shadow economy" through the search and return of property acquired through corruption;

will improve the country's position in the Corruption Perceptions Index and other prestigious international rankings; 
more effective coordination of law enforcement agencies will be a factor in optimizing their workload.

\section{REFERENCES}

1. Decree of the President of the Republic of Uzbekistan "On the Strategy for the further development of the Republic of Uzbekistan" 07.02.2017 No. 4947 https://lex.uz/search/nat?actnum=4947

2. Entry bribe // Russian newspaper. 2012. - September 28. - No. 5897 ; Kimlatsky O.A., Machulskaya I.G. On the state of the fight against corruption in the Russian Federation // Analytical Bulletin of the Council of the Federation of the Federal Assembly of the Russian Federation "Actual problems of combating corruption." 2008. - No. 6 (351). - URL: http: //www.council. gov.ru/fi les / analitical_bulletin / 309.zip; Yusupov M.R. Institutions of civil society and entrepreneurship in Russia as subjects and factor in the implementation and improvement of anti-corruption legislation // Analytical Bulletin of the Council of the Federation of the Federal Assembly of the Russian Federation "Anti-corruption: problems and prospects of legislative support." 2012. - No. 10 (453). - URL: http://www.council.gov.ru/inf_sl/bullet in/item/416/

3. A.F. Pavlov, S.V. Mironov. On the issue of institutionalization of corruption prevention through the creation of a single anti-corruption body. Dialectics of anti-corruption. "Actual problems of economics and law." 2012. No. 4, - P. 81. A.A.Smagulov, V.V. Shabunya Overview of the Third Eurasian Anti-
Corruption Forum "Modern Standards and Technologies for Combating Corruption" (Moscow, April 24-25, 2014) Journal of Foreign Law and Comparative Law No. 3, 2014. - S. 442464.

4. Law of the Republic of Uzbekistan "On accession of the Republic of Uzbekistan to the United Nations Convention against Corruption (New York, October 31, 2003)" No.158 of 07.07.2008. https://lex.uz/docs/1369505

5. Law of the Republic of Uzbekistan "On Combating Corruption" dated 03.01.2017 No-419. https://lex.uz/search/nat?actnum=419 \&fform_id=3968

6. https://www.transparency.org/country IUZB

7. Address of the President of the Republic of Uzbekistan Shavkat Mirziyoyev to the Oliy Majlis. https://president.uz/uz/lists/view/3324

8. Anti-corruption and public control systems will be improved. https://prezident.uz/uz/lists/view/3350

9. Decree of the President of the Republic of Uzbekistan No. 5953 of 02.03.2020 "On the State Program for the implementation of the Action Strategy for the five priority areas of development of the Republic of Uzbekistan in 2017-2021 in the" Year of Science, Enlightenment and Digital Economy https://lex.uz/search/nat?actnum $=5953$

10. M.M. Polyakov Specialized anticorruption bodies of state power and officials in Russia and foreign countries. Bulletin of the University named after O.E. Kutafin. 2019, - S. 158164. https://cyberleninka.ru/article/n/spetsi 
alizirovannye-antikorruptsionnyeorgany-gosudarstvennoi-vlasti-idolzhnostnye-litsa-v-rossii-izarubezhnyh-stranah/viewer

11. OESR, Specialized anti-corruption institutions: a review of models. Second edition, 2013. https://www.osce.org/ru/secretariat/4 24898?download=true

12. https://www.icac.org.hk/tc/home/inde x.html

13. Law of Ukraine "On the National AntiCorruption Bureau of Ukraine". https://zakon.rada.gov.ua/laws/show/1 698-18

14. https://www.fbi.gov/investigate/public -corruption

15. Report: second half of 2019 https://nabu.gov.ua/report/zvit-drugepivrichchya-2019-roku

16. Corruption Perception Index: Ukraine for the year fell by 6 places in the ranking.

https://delo.ua/econonomyandpoliticsi nukraine/indeks-vosprijatija-korrupciiukraina-za-god-upa-363724/

17. The Prosecutor General's Office of Ukraine has begun criminal proceedings against the director of NABU

https://www.interfax.ru/world/587764; The Prosecutor General's Office calls the director of the NABU for interrogation https://interfax.com.ua/news/general/ 585942.html

18. Anti-corruption Guide. Organization for Security and Co-operation in Europe (OSCE), www.osce.org 2016, Vienna, Austria. - S. 154. http://en.nbpublish.com/library_get_p df.php?id=21250

19. J. Marc Fight against corruption in France. Journal of Foreign Legislation and Comparative Law No. 3, 2012. - P. 34-37

20. https://www.quinnemanuel.com/thefirm/publications/article-february-2017french-anti-corruption-law-reform/

21. http://kremlin.ru/structure/councils\#in stitution-12

22. Tsirin A.M., Cherepanova E.V., Tulinova O.A. Modern standards and anticorruption technologies // Journal of Russian Law. 2014. No. 7. P. 143 - 171

23. https://www.transparency.org/country ISGP

24. Prevention of Corruption Act Status: Current version as at $07 \mathrm{Apr} 2020$. https://sso.agc.gov.sg/Act/PCA1960

25. https://www.transparency.org/country /HKG

26. https://www.gov.hk/en/about/abouthk /factsheets/docs/icac.pdf

27. https://www.transparency.org/country /LTU

28. https://www.transparency.org/country /LVA 